\title{
Philosophical-religious Legacy as the Basis for the National Identity and Humanitarian Education of Modern Russia*
}

\author{
Olga Chistyakova \\ Faculty of Humanities and Social Sciences \\ Peoples' Friendship University of Russia \\ 6 Miklukho-Maklaya Street \\ Moscow, Russia \\ E-mail: olgachis@yandex.ru
}

\begin{abstract}
For centuries, the Russian state existed in close relationship with the Russian Orthodox Church and based on its values. Those values were accepted by the vast majority of the population and became not only religious values but dominated all spheres of social life. Thinkers of early Christianity elaborated the basic concepts of man and society, which later found the reflection in the Russian religious philosophy of the late 19th - early 20th centuries. In the author's view, these religious-philosophical ideas can be seen as the theoretical foundations for maintaining the national cultural identity and humanitarian education in modern-day Russia. Additionally, the philosophical concepts of the Russian spiritual heritage can be used for maintaining a cultural dialogue with representatives of various religions, ethnic and social groups. Identity and education of a contemporary state should be maintained with the help of such dialogue. The author argues that humanitarian education in Russia should be based on the historical experience, traditions, and, at the same time, considers the actual realities of modern society.
\end{abstract}

Keywords-cultural and religious identity; national identity; national education; Russian religious philosophy; Orthodox Church; intercultural dialogue

\section{INTRODUCTION}

The prospects of development of the modern-day Russian society are intertwined closely with the origins of the national culture, with ideas, expressing the specifics of the Russian national identity. At the same time, Russia's historical and cultural experience is so vast that it cannot be taken out of the process of joint development of the Western and Eastern countries. Not by chance the best thinkers of the "Russian spiritual Renaissance" (the late $19^{\text {th }}-$ early $20^{\text {th }}$ centuries) noted, that Russia has the universal designation, highlighting the "Russian-Christian" way of the nations' development (E. Trubetskoy), allowing them to enter the global civilization. In the following article, we review the major philosophical and religious ideas of the Russian heritage that, due to their insightful content, may serve as the moral foundation for both the cultural identity of our society

*The publication has been prepared with the support of the "RUDN University Program 5-100" as well for the academic humanitarian training.

\section{INDIVIDUALISM AND SOBORNOST AS THE PRINCIPLES OF PUBLIC LIFE: HistORICAL BACKGROUND}

For many centuries, the Russian national identity was in concordance with the provisions of the Orthodox Church. The most important principles of the state system and national culture, presented by the Orthodoxy and the Russian religious philosophy, are the principles of sobornost (from "sobor" - gathering, assemblage) and anthropocentrism (according to which a person is at the center of philosophical and religious scrutiny).

The orientation of Russian philosophy at personality, solution of the meaningful problems, and the disclosure of the existential nature of a human being has a long story and its origins are found in Greco-Byzantine Patristics. It is a widely known fact, that during the first centuries of its existence, the Eastern (Greek) and Western (Latin) branches of Christianity were developing in integrity and unity.

In the 11th century happened the Great Schism, i.e. the break of communion between what are now the Eastern Orthodox and Roman Catholic churches. Many scholars see the origins of the Schism in the political struggle and economic claims. We, however, believe that the causes of disagreement between the Western and Eastern churches consisted precisely in the interpretation of dogmatic creeds.

Yet, despite the still present irreconcilable dogmatic differences between Catholicism and Orthodoxy, there is a historically formed concept of combining these two branches of Christianity. We are talking about the Christian doctrine of a Man, which, despite the overwhelming theocentrism of the Christianity, has an independent and peculiar status. This religious-anthropological doctrine was secured by the Ancient Greek philosophy, as the works of Plato, Aristotle, the Neo-Platonists, and others were used by the Holy Fathers to justify the relationship between God and a man with the possibility to cognize the Absolution. It should be noted, that the Christian anthropology, although showing distinctions in interpretations in the works of Augustine of Hippo, Thomas Aquinas, Basil of Caesarea, Gregory of Nyssa, Gregory of 
Nazianzus, Nemesius, was able to elaborate the elements of sobornost of not only the two Churches but also of some current societies, introducing spiritualized and moral factor in their livelihoods.

In author's view, the Christian anthropological concept partially erases the so-called civilizational differences between the West (Europe and the USA) and Russia. The Orthodox theologians, e.g., see the overcoming of such differences in the recovery of the ideas of humanism and unity, including in the modern Western civilization that used and nurtured individualism as the basic principle of existence. Following that point of view, the implementation of the individualism into internal affairs destroys the basic principle of the Christian Church, once elaborated at the dawn of Christianity, and which served as a substantial basis to the Russian public life until 1917. We are talking about the concept of sobornost, closely associated with ideas of community, intercultural and interreligious unity of peoples. It is argued, that sobornost may be restored in the Russian society and culture in joint cooperation with the Russian Orthodox Church. However, the ideological confrontation of the West - Russia is presented as a conflict between two paradigms: individualism - sobornost.

\section{WHETHER IT IS REALITY OR NOT}

In order to answer this question, it is necessary to restore the continuity of the Russian culture from its origins, including primary sources of the Early Christianity. We focus our spotlight on the works of the Holy Fathers of the Eastern (Greek-Byzantine) Church, who in the 4th-8th centuries developed the anthropological concept of Christianity along with the formation of the Christian dogma (inseparable from the Western, Latin, Church).

\section{THE SUCCESSION OF THE IDEAS OF PATRISTICS AND RUSSIAN RELIGIOUS PHILOSOPHY}

A positive trait of the Orthodox Patristics discourse is in its independence from the state's political and economic doctrines. The backbone of the Patristics heritage supports the progressive development of the spiritual culture and education, justifies the way of overcoming the cultural crisis, which is presented as the rise of spiritual creativity of the people and the priority of rationalism, not excluding, however, the value of human individuality.

The correlation of Patristics ideals with modernity doesn't mean bare copying or imitation. The legacy of the Holy Fathers allows understanding, how applicable is that kind of culture for the modern people, for the approval of the creative power, fulfillment, education, and self-identity. It seems to us, that a certain philosophical reflection on the situation of the Christian anthropology could be moral and culture-forming sources of any modern state's existence.

If we rewind to the era of the formation of the Christian faith, we will see, that back then a new style of cultural behavior evolved gradually, which supposed that the human values are more important than the national or class ones, and the overall development of culture, along with canonization and authoritarianism, introduced humanistic orientation and refocused ethical concepts in the direction of spirituality and universal sense.

Nonetheless, Christianity didn't prevent the various ethnic groups to preserve their peculiarities or "cultural styles". A distinct feature of Christianity was a cultivation of personal existence. Moreover, the affirmation of human life in the name of eschatological salvation became a kind of a self-referential purpose of this cultural paradigm.

The center of the Orthodox culture was its understanding of the personality, its essence and the expediency of existence. The concept of personality was of a particular interest to the Greek-Byzantine Holy Fathers, as it was considered to be a personal and direct communion in the spirit (which was reflected later in the concept of sobornost). A person in Christianity is the personality in spirit, and an individual by physical nature. The philosophical plot of the Eastern Christian anthropology is the assertion that a holistic person, rooted into the earthly existence by the right of possessing the image of God and inspired by the Holy Spirit, may serve the basis and purpose of the objective world [1].

Exactly the Spirit in the Orthodox cultural tradition appears capable of leading a human beyond the objective world, acts as the condition of possible transcendence, which can be achieved only in the perfection of nature, common to all people, called by Gregory of Nyssa the "unity of human nature". Approaching through spirit and mind the Absolution, an individual becomes open to the world of Divinity.

Thus, the religious thinkers Lactantius, Irenaeus, Athanasius of Alexandria, Gregory of Nyssa, Gregory of Nazianzus and others, cultivated the image of the only creature in the world, capable of eliminating the dualism of the Divine and earthly worlds, and reconciling the spiritual and material existence. The challenge begets the cosmic purpose of the universal personality: to lead the imperfect earthly world to harmony and the Divine consent. Gregory of Nazianzus remarkably defined man as a creature, "stopping a feud" between body and spirit. He wrote, "I consist of body and soul. And the soul is the infinite jet of light - Deity; and the body is a derivative of the dark beginning. If I make up one common nature, the feud within me is stopped. For not the hostile, but friendly beginnings find common grounds?" [2]. Human nature is directed at spiritual equality with God, and, therefore, at the establishment of absolute harmony in the earthly world.

Maximus the Confessor argued that the main purpose of a human is the unification of the earthly world with Logos, but in order to reach it, a human should undergo deification in himself, as he is the microcosm, integrating all the elements of macrocosm and the Universe. These ideas show the greatness of the human destiny and the tragedy of his misunderstanding of the own purpose and the abuse of freedom. These ideas are still relevant in the beginning of the third Millennium.

Curious continuation of the Patristics ideas is found in the existential works of Nikolai Berdyaev. The philosopher claimed that a person is not a particle of the Universe or 
genus but on the contrary society is a part of the holistic personality, as the basis of the latter is the spirit, bringing a human from the world of objectification to the transsubjective world in order to meet God. Berdyaev wrote: "The triumph of the spiritual origin doesn't mean the subordination of man to the Universe but the revelation of the Universe in the personality" [3]. Society and state are the limits of human freedom. So, the antimony of an individual and society can never be solved from two points of view the philosophy of society and the philosophy of spirit. Any form of society is, in fact, tyrannical in respect to the individual's identity, human spirit ('the slavery of being'). Therefore, the problem of the relationship between an individual and a society is possible only in the frameworks of the philosophy of spirit from the Christian personalist outlook.

The basis of this doctrine is the recognition of an individual as a spiritual being and spiritual unity of all people on the basis of love and service to God. In order to be realized, the union requires the transformation of a human through the world of culture, spiritual values, creativity. Only the spiritual community frees a man. "Spirit is freedom, and freedom is the victory of the spirit" [4], - so Berdyaev. The history of society is a theandric process, having an eschatological meaning. But the hope for the future Berdyaev linked with an appeal to the objectified real world and the enlightenment through the intelligent creativity of an individual. For Berdyaev, creativity is cooperation between a man and a God; this is "the human response to the call of God". One needs a free effort of the spirit to prevent decomposition of Self, split and disintegration of personality.

The Holy Fathers of the Greek-Byzantine Church claimed that the task of man is to elevate the mind above the usual level and to hunt down the roots in soul, that tie an individual with the vital integrity of the whole human race. However, the integrity of the human community should not degenerate into total subordination of an individual to the society and state. Therefore, remains the problem of the relation of human's inner freedom and its limitations in various social and economic forms of dependence. As the individual spirit of a person is the fundamental level of human reality, the idea of inner spiritual rebirth, performed in a free, i.e. not forced, way, carried to the crest by the Byzantine thinkers, stays meaningful and relevant [5].

The Orthodox thinker Gregory of Nyssa pointed out rightly that personality is a freedom from natural necessity, the ability to freely determine Self, to go beyond own individuality to convert it in terms of absolute rules and values. Human freedom in the writings of the early Orthodox sages was directly connected with the Reason and rationality of human activity. A person knowingly "leads his nature", having power over own actions and desires. "Out of necessity the freedom of decisions is connected with the mind, as either, a person will not be a rational being, or, being rational, will be an independent master of his own actions", - claimed John of Damascus [6]. What was being cultivated in the West, was slowly losing its positions in Russia.
The process of personal self-determination was seen by the religious thinkers as coinciding with the process of knowledge of God and self-knowledge. At the same time, the revelation of the possibilities of self-knowledge in theology had a secular value as well, as it made emphasis on the cultivation of internal qualities of a human being, developed his psychological characteristics, and "taught" the art of human control with all its multiplicity of energies, thoughts, aspirations. In the Orthodox anthropology, the human selfmeditation is a feeling of self and a way to self, i.e. the process of self-awareness and self-identity through the search for moral ideals through a comparison of own actions with the Absolute morality of God. Personal consciousness and knowledge of the Divine grow, as a man becomes more and more perfect and free.

A modern man finds it important, that Patristics thought outlines one of the mechanisms of individual human selfdetermination, designs the personal purpose as a creative search for the valuable sense of existence. From the orientation at the activity of a person, at faith in his spiritual abilities, emerged the most important religious-philosophical statement that remains rational even today: perfect life, either personal or public one, is being created by a human naturally and objectively. To quote N. Berdyaev, a person should free himself "from the slavery of the state, society, nature, and civilization", however, an individual should not cross the thin line between freedom and anarchy. Otherwise, a beautiful Christian postulate of the human freedom of selfdetermination turns into the means of justification of the violence, permissiveness, and chaos.

No one, especially no state officials or politicians, should hide behind the Christian or any other form of religious ideas to solve economic, military, financial problems or just to realize their political ambitions. Sobornost (unity) and anthropocentrism, in our opinion, should be the basis of the national Weltanschauung, the determining factor of the spiritual life of any state, whether in the West or in Russia. This provides grounds for considering the Christian anthropological practices and the ideas of the Russian religious philosophers as a theoretical and moral basis of humanitarian education.

\section{PHILOSOPHICAL-RELIGIOUS CONCEPTS AND RUSSIAN EDUCATION}

We are convinced, that spiritual and cultural component of the current youth may in the nearest future affect the establishment of civilized relations among numerous ethnic groups in Russia, as well as among the various religious associations and organizations, officially operating in the country.

Not being a supporter of a sharp opposition between secular humanism and religious humanism, secular morality and religious (in particular. Christian) morality, the author of this article believes that many ideas and concepts, once shaped by the Eastern Orthodox Church and, later, Orthodoxy, may quite naturally enter the Russian educational process in the higher school. After all, many of the provisions of Orthodox Christianity bring to the 
philosophical reflection the ideological values and correspond to the historical-cultural archetype of the Russian mentality.

In this context, we see a rational kernel in lecturing special religious disciplines from the point of their philosophical and cultural meaning in the curricula of the higher education. "The modern state of the Russian education is still in the process of reformation and it should consider all the actual problems of our society. The introduction to the higher education the special courses of philosophical-religious nature, could make a constructive contribution to the formation of the values, spirituality, deep ideological positions among students and deepen their knowledge in the fields of history and theory of religious traditions" [7]. It is appropriate in this respect to cooperate with theologians and representatives of the traditional religions having an experience in lecturing and research.

Artificially constructed opposition between the secular and religious knowledge impoverishes a human, his culture, and inner world. Academic course on philosophy starts nowadays with the division of philosophical and religious worldviews without finding any common ground. And if the division on the faculties of Humanities is partially removed by the subsequent immersion in the certain knowledge, by the study of history, and, partially, the conceptual provisions of religions, then in technological higher schools the students form a certain sketchiness of thinking. In the minds of young people, there is a purposefully laid principle of the opposition of science and religion without any hope of interaction between them.

It seems to us that reliance only on scientific knowledge will never make an individual more humane, as humanity is born from the eternal search for the meaning of life, unattainable by purely scientific thought [8]. People will never become more moral, will never comprehend their spiritual essence, armed only with logic.

\section{PIETY AND NATIONAL CUlTURAL IDENTITY}

The aforementioned philosophical and religious ideas fill with a certain content the concept of national cultural identity. State identity is due to the harmonious combination of the spiritual values of peoples, living in the same territory. The peoples may be united only by the moral and cultural paradigm, reflecting the centuries of experience and rooted tradition on one hand, and the modern realities on the other. The Christian anthropological conception, which finds its continuation in the works of the Russian religious thinkers, was able to formulate universally valid categories, axiological regulations that can potentially bind together different ethnic groups, despite the diversity of religions, languages, and social statuses. Moral religious imperatives, getting shades of secularity, are capable of neutralizing the violently dissonant contradictions among people and governments, resulting in conflicts and social explosions.

The state grows stronger not only through military expenditures. In the developed countries population may stay poor in both material and moral spheres. The state is strong in its spirit, culture, and ethics. In our opinion, Russian cultural identity can be successfully realized through the Christian anthropological values, as they carry a high moral content in addition to the philosophical basis. This suggests that they may be regarded not only as religious but also as secular categories and imperatives. For example, the concept of the Holy Trinity provides an insight into the perfect human relations based on spiritual unity, equality, justice, and cooperation. The concept of personality was one of the criteria for a conceptual consideration of God - human interaction in the Eastern Patristics and in Russian religious philosophy of the $19^{\text {th }}$ and $20^{\text {th }}$ centuries. So, the religious concept of personality could become a basic component of the Russian national identity as well of the cultural identity of multi-ethnic Russia.

\section{CONCLUSION}

This very article is not, in any case, the idealization of the Christian values, and not the determination to translate morality on the purely religious soil. This is more an attempt to draw attention to personality that should occupy the central place in our society and culture. In the end, everything is done by the man himself and in the name of men but not always for the good of men. In one of the Oscar Wilde's stories, people came to God to complain about the wars, violence, evil, tears of the elderly people and children. God replied: "You don't like it, so don't do it!".

So, does it matter, what personified God utters these words?

Pope John Paul II expressed his understanding of religion as follows: "the various religions were so many reflections of the one truth" [9]. It seems to us, that in this case, the Truth itself spoke through Pope.

\section{REFERENCES}

[1] O.V. Chistyakova. Byzantium - Russ - Russia. Philosophical and Anthropological Traditions. Textbook. Kuban State University Press, Krasnodar-Moscow, 2005.

[2] Gregory of Nazianzus. Word on Peace. // Collected Works. In 2 Vols. $\mathrm{SPb}$, without year, p. 25.

[3] N.A. Berdyaev. Slavery and Freedom. / Berdyaev N.A. The Realm of Spirit and the Realm of Caesar, p. 17.

[4] Ibid., p. 149.

[5] O.V. Chistyakova, Postmodernism, Christian Patristics, and Values of Peace in the Modern Cultures In the Context of Educational Process // Proceedings of the 2016 International Conference on Arts, Design, and Contemporary Education. Volume 64 (ICADCE 2016) Advances in Social Science, Education and Humanities Research. Atlantis Press, Paris, France, 2016.

[6] John of Damascus, An Exact Exposition of the Orthodox Faith. I Rostov-on-Don, 1992, p. 109.

[7] O.V. Chistyakova, The Interaction of Social, Educational and Religious Institutions in a Postsecular Society // Proceedings of the 3rd International Conference on Arts, Design and Contemporary Education (ICADCE 2017). Advances in Social Science, Education and Humanities Research. Vol. 144. Moscow, Russia, May 29-30, 2017. Paris: Atlantis Press, 2017, p. 539.

[8] T.G. Leshkevich, Philosophical meaning of modern transformations of education // Proceedings of the 3rd International Conference on Arts, Design and Contemporary Education (ICADCE 2017). Advances in Social Science, Education and Humanities Research. Vol. 
144. Moscow, Russia, May 29-30, 2017. Paris: Atlantis Press, 2017,$961 \mathrm{p}$.

[9] Redemptor Hominis, 19, March, 22, 1979. 